\title{
温州ミカンの品質を予測するニューラルネットワークモデル
}

\author{
森本哲夫 ${ }^{1} \cdot$ 大内義典 $^{2} \cdot$ 芳之内正幸 $^{2}$ \\ 1 愛媛大学農学部 790-8566 松山市樽味 3-5-7 \\ 2 愛媛県農林水産部 790-8570 松山市一番町 4 丁目 4-2
}

\section{A Neural-Network Model for Predicting the Quality of 'Satsuma' Mandarin}

\author{
Tetsuo Morimoto ${ }^{1}$, Yoshinori Ouchi ${ }^{2}$ and Masayuki Yoshinouchi ${ }^{2}$ \\ ${ }^{1}$ Dept of Biomechanical Systems, Ehime University, 3-5-7 Tarumi, Matsuyama, 790-8566, Japan \\ ${ }^{2}$ Agriculture, Forestry and Fisheries Department, Ehime Prefecture, \\ 4-4-2 Ichiban-cho Matsuyama, 790-8570, Japan
}

\begin{abstract}
A neural-network model was developed to predict the quality of 'Satsuma' mandarin during the final (harvesting) stage based on the past time series of both climate data and fruit-quality data. The time course changes in the climate data and fruit-quality data were collected from August to November, 1996 through 2002, and seven types of data sets were obtained during these seven years. Among them, six types of data sets were used for learning and one data set for validation. The climate factors that had the highest effect on the sugar content and citric acid of the fruit were rainfall and sunshine duration. Therefore, both the rainfall and sunshine duration were defined as input variables, and both the sugar content and the citric acid of the fruit as output variables for the modelling. It was difficult to model the relationship between the measured input and the measured output because they had a nonlinear correlation and large dispersion. However, the use of the time-series data for both the input (climate) and the output (fruit-quality) and choice of the optimal parameters for iteration number for learning, system parameter number and hidden neuron number provided good predictions.
\end{abstract}

Keywords : fruit-quality, neural network, prediction, 'Satuma' mandarin, time series

\section{緒言}

従来より，作物の生育を予測するため，いろいろなモ デルがつくられてきた (Thornley, 1976)。とくに最近 は，対象の非線形特性をうまくモデル化できるニューラ ルネットワークの利用が多くなっている。たとえば, Elizondo et al. (1994) は, 大豆の栽培において, 日及 の最低温度, 最高温度, 日長, 定植後（または開花後）

2004 年 12 月 10 日受付

2005 年 3 月 2 日受理

Corresponding author: Tetsuo Morimoto (morimoto@agr.ehime-u.ac. jp)
の日数のデータから大豆の開花日（または大豆の成熟度 合い）を予測するニューラルネットワークモデルを構築 した.このモデルは, 入力 (気象条件, 生育条件など) と出力 (生育結果) の静的な関係をモデル化したもので あり, 従来の統計的手法 (回帰曲線) よりも予測精度が 高いことを示した。 その他, 芝生の生長予測（Tan and Smeins, 1996), 藻の開花の予測 (Recknagel et al., 1997）などに利用されている. 一方, Liu et al. （2001）は，トウモロコシの収量を予測するのに，経時 変化（動的な特性）を考慮し, 土壤の $\mathrm{pH}$, 肥料濃度, 栽植密度などの栽培条件の他に，5，6，7，8月の降雨 量の時系列データを入力としたニューラルネットワーク モデルを構築した。このモデルは, 降雨量の経時変化に 対する生育特性をモデル化しているので, 一種の動的モ 
デルであり, この場合, 出力は入力の時系列データのみ から予測しているので, MA (moving average) モデ ルに対応する．動的なモデル化（もしくは動的な同定） の利点は, 時間的変化に基づいてモデル化するので，シ ステムの挙動が捉えやすく, より正確なモデルができる. また，入力としての環境条件をどのように操作してやれ ば出力 (生長量, 品質) が良い結果になるか, その時間 的変化が見極めやすく，モデルベースの予測制御などに 利用しやすい. しかし, この場合, 出力 (収量) は入力 （栽培および気象条件）のみから予測しているので, 出 力にばらつきが多ければ，予測精度が低下する。

それで，システム同定におけるARMA（autoregressive moving average) モデルのように, 入力の時系列 と出力の時系列の両方を利用すればもっと正確なモデル ができる (Fasol and Jorgl, 1980; Strejc, 1980; Sagara et al., 1981). すなわち, 出力の未来值を予測する場合, 入力の時系列だけでなく, 出力の過去の時系列も利用し た方が予測精度は向上する。

そこで本報では，温州ミカンの最終的な品質を予測す るため, ニューラルネットワークを利用して，一つ先 （1 ケ月先で 11 月の収穫期）の糖度とクエン酸含量を, それまでの（8～10月までの）気象変動および糖度とク エン酸含量の過去の時系列データから予測するモデルを 構築した.

\section{材料および方法}

\section{1. 供試材料}

供試材料は愛媛県の八幡浜で栽培されている宮川早生 温州ミカン (Citrus Unshu Marcorv.) である。果実の 品質計測については, 果実が発育, 成熟する段階の 8 〜 11 月にかけて 1 ケ月毎に 6 個（3 本 $\times 2$ 個/本）の果 実を選んで糖度とクエン酸含量を測定し，それぞれ平均 值を求めた，気象データについては，近隣の八幡浜消防 署で測定されたデー夕を利用して，各月で 1 日当たりの 平均値を求めた。

果実の糖度は屈折糖度計（Atago，ATC-20 E）を用 いて測定した。また，クエン酸含量は水酸化ナトリウム 液による滴定法（Hirose, 1987）で測定した。

\section{2. モデル化の方法}

本報におけるモデル化は，システム同定における ARMA モデルのように, 入力の時系列と出力の時系列 の両方を利用する。すなわち，（1）式および図 1 に示す ように, 出力 (果実の品質) の一つ先 $(\mathrm{k}+1)$ の予測值 $\mathrm{y}(\mathrm{k}+1)$ は, 入力 (気象条件) の一つ先 $(\mathrm{k}+1)$, 現在 $\mathrm{k}$,

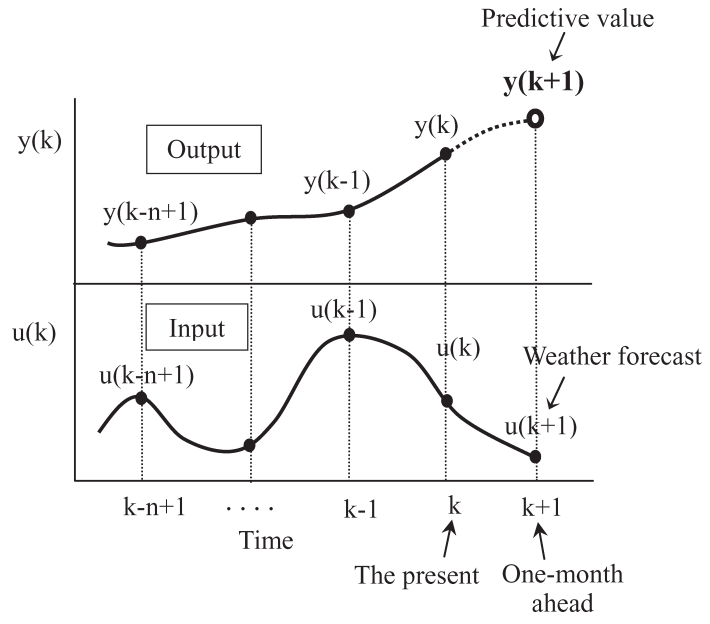

図 1 一つ先 $(\mathrm{k}+1)$ の出力值 $\mathrm{y}(\mathrm{k}+1)$ を, 現在 $\mathrm{k}$ お よび $(\mathrm{k}-\mathrm{n}+1)$ 時点前までの出力時系列 $\{\mathrm{y}(\mathrm{k})$, $\mathrm{y}(\mathrm{k}-1), \cdots, \mathrm{y}(\mathrm{k}-\mathrm{n}+1)\}$ と一つ先 $(\mathrm{k}+1)$, 現 在 $\mathrm{k}$, そして $(\mathrm{k}-\mathrm{n}+1)$ 時点前までの入力時 系列 $\{\mathrm{u}(\mathrm{k}+1), \mathrm{u}(\mathrm{k}), \mathrm{u}(\mathrm{k}-1), \cdots, \mathrm{u}(\mathrm{k}-\mathrm{n}+1)\}$ から予測する方法（n：システムパラメータ 数)

Fig. 1 A method for predicting the next (final) value of the output $y(k+1)$ from the next value of the input $\mathrm{u}(\mathrm{k}+1)$ and the past time series of the input $\{\mathrm{u}(\mathrm{k}), \mathrm{u}(\mathrm{k}-1), \ldots, \mathrm{u}$ $(\mathrm{k}-\mathrm{n}+1)\}$ and the past time series of the output $\{\mathrm{y}(\mathrm{k}), \mathrm{y}(\mathrm{k}-1), \ldots, \mathrm{y}(\mathrm{k}-\mathrm{n}+1)\}$. Here, the next value of the input $\mathrm{u}(\mathrm{k}+1)$ is obtained from one-month ahead weather forecast ( $\mathrm{n}$ : number of system parameter).

そして $(\mathrm{k}-\mathrm{n}+1)$ 時点前までの時系列 $\{\mathrm{u}(\mathrm{k}+1), \mathrm{u}(\mathrm{k})$, $\cdots, \mathrm{u}(\mathrm{k}-\mathrm{n}+1)\}$ と出力の現在および $(\mathrm{k}-\mathrm{n}+1)$ 時点前 までの時系列 $\{\mathrm{y}(\mathrm{k}), \cdots, \mathrm{y}(\mathrm{k}-\mathrm{n}+1)\} \quad(\mathrm{n}$ : システムパラ メー夕数) から推定する (Chen, et al., 1990; Narendra and Parthasarathy, 1990; Isermann et al., 1997). 一つ 先の入力值 $\mathrm{u}(\mathrm{k}+1)$ および入出力関係を表す関数 $\mathrm{f}(\cdot)$ が与えられれば，他は既知なので，一つ先の出力值 $\mathrm{y}(\mathrm{k}$ $+1)$ が求められる.

$$
\begin{aligned}
\mathrm{y}(\mathrm{k}+1)= & \mathrm{f}(\mathrm{u}(\mathrm{k}+1), \mathrm{u}(\mathrm{k}), \cdots, \mathrm{u}(\mathrm{k}-\mathrm{n}), \\
& \mathrm{y}(\mathrm{k}), \cdots, \mathrm{y}(\mathrm{k}-\mathrm{n}+1))
\end{aligned}
$$

具体的には，1 ケ月先（11月）の出力值 $\mathrm{y}(1)$ は，1 1 ケ 月先の入力值 $\mathrm{u}(1)$, 現在まで $(10,9,8$ 月) の入力時系 列 $\{\mathrm{u}(0), \mathrm{u}(-1), \mathrm{u}(-2)\}$, 現在までの出力時系列 $\{\mathrm{y}(0)$, $\mathrm{y}(-1), \mathrm{y}(-2)\}$ から予測する。なお， 1 ケ月先の入力值 $\mathrm{u}(1)$ は天気予報の 1 ケ月予報から得られる.

\section{3. ニューラルネットワークによる予測モデル}

本報では，図2（a）に示すように，2 入力（降雨量 と日照時間) -2 出力 (糖度とクエン酸含量) システム 
を想定し，ニューラルネットワークを用いて動的モデル (black-box model) を構築する。なお， 2 入力にする 理由は図 3 の計測結果の項で述べる. 図 2 (b) はその 場合のニューラルネットワークである. 入力層, 隠れ層, 出力層の 3 層から成る. 動的モデルを構築するため, 時 間遅れオペレータを導入し, 入力と出力の時系列をつく る. 学習は, 計測データを基に, 二つの入力時系列 $\left\{\mathrm{u}_{1}(\mathrm{k}+1), \mathrm{u}_{1}(\mathrm{k}), \cdots, \mathrm{u}_{1}(\mathrm{k}-\mathrm{n}+1)\right\}$ と $\left\{\mathrm{u}_{2}(\mathrm{k}+1), \mathrm{u}_{2}(\mathrm{k}), \cdots\right.$, $\left.\mathrm{u}_{2}(\mathrm{k}-\mathrm{n}+1)\right\}$ および二つの出力時系列 $\left\{\mathrm{y}_{1}(\mathrm{k}), \cdots, \mathrm{y}_{1}(\mathrm{k}\right.$ $-\mathrm{n}+1)\}$ と $\left\{\mathrm{y}_{2}(\mathrm{k}), \cdots, \mathrm{y}_{2}(\mathrm{k}-\mathrm{n}+1)\right\}$ を入力層に入れ, ま た一つ先に対応する二つの出力值 $\mathrm{y}_{1}(\mathrm{k}+1)$ と $\mathrm{y}_{2}(\mathrm{k}+1)$ を出力層に入れて行う $(\mathrm{k}=0,1,2, \cdots, \mathrm{N}, \mathrm{N}+1:$ Data number, n: System parameter number). 学習後にお ける予測は，(1) 式に従って計算され，一つ先の出力の

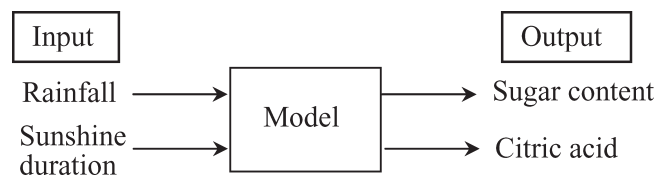

(a) A two-input two-output system

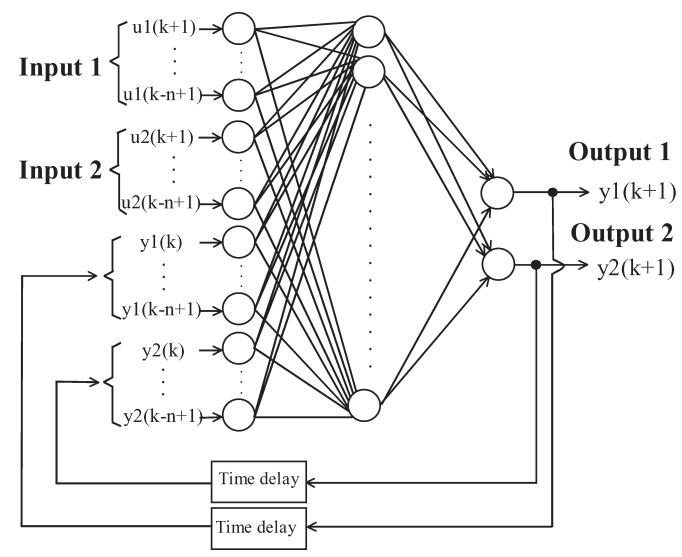

(b) A three-layer neural network

図 22 入力 -2 出力動的システムを同定するための 3 層の階層型ニューラルネットワーク

Fig. 2 A three-layer neural-network model for identifying a two-input two-output dynamic system
予測值 $\left(\mathrm{y}_{1}(\mathrm{k}+1)\right.$ と $\left.\mathrm{y}_{2}(\mathrm{k}+1)\right)$ は，1 ケ月予報で得られた 一つ先の入力值 $\left(\mathrm{u}_{1}(\mathrm{k}+1)\right.$ と $\left.\mathrm{u}_{2}(\mathrm{k}+1)\right)$ とそれまでの入力 值 $\left\{\mathrm{u}_{1}(\mathrm{k}), \cdots, \mathrm{u}_{1}(\mathrm{k}-\mathrm{n})\right\}$ と $\left\{\mathrm{u}_{2}(\mathrm{k}), \cdots, \mathrm{u}_{2}(\mathrm{k}-\mathrm{n})\right\}$ 加ら推定 される。

学習法はネットワークの出力と教師信号との誤差が最 小となるように，ネットワークの荷重係数としきい值を 勾配法に基づいて調整する通常のエラーバックプロパゲ ーションである (Rumelhart, et al., 1986; Hint, 1992). すなわち, 中間層ニューロン $\mathrm{j}$ から出力層ニューロン $\mathrm{k}$ への荷重係数の修正量 $\Delta \mathrm{W}_{\mathrm{jk}}$ は, 次式のように, 誤差に 関係する要素 $\mathrm{d}_{\mathrm{k}}$ と一つ前の修正量 $\Delta \mathrm{W}_{\mathrm{jk}}(\mathrm{old})$ から求め るモーメント法を採用した（Nakano et al., 1990). し きい值の修正量 $\Delta \mathrm{h}_{\mathrm{k}}$ も同様である。このときの学習係 数は $\alpha=0.08$, モーメント係数は $\beta=0.8$ とした.

$$
\begin{aligned}
& \mathrm{d}_{\mathrm{k}}=\left(\mathrm{T}_{\mathrm{k}}-\mathrm{O}_{\mathrm{k}}\right) \cdot \mathrm{O}_{\mathrm{k}} \cdot\left(1-\mathrm{O}_{\mathrm{k}}\right) \\
& \Delta \mathrm{W}_{\mathrm{jk}}=-\alpha \cdot \mathrm{d}_{\mathrm{k}} \cdot \mathrm{Y}_{\mathrm{j}}+\beta \cdot \Delta \mathrm{W}_{\mathrm{jk}}(\text { old }) \\
& \Delta \mathrm{h}_{\mathrm{k}}=\alpha \cdot \mathrm{d}_{\mathrm{k}}+\beta \cdot \Delta \mathrm{h}_{\mathrm{k}}(\mathrm{old})
\end{aligned}
$$

ただし， $\mathrm{O}_{\mathrm{k}}$ はネットワーク（出力層ニューロン k）か らの出力, $\mathrm{T}_{\mathrm{k}}$ は $\mathrm{O}_{\mathrm{k}}$ に対応する教師信号, $\mathrm{Y}_{\mathrm{j}}$ は一つ前 の層のニューロン $\mathrm{j}$ からの出力值である.

\section{結果および考察}

\section{1. 気象条件に対するミカンの糖度とクエン酸含量 の応答}

まず，同定用のデータを示す。図 3 は 1996〜2002 年 までの各年における 8〜11月にかけての降雨量, 日照時 間，気温とそれに対する温州ミカンの糖度とクエン酸含 量の経時変化である. 1996〜2002 年（7 年間）の各年に おける入出力データを順番に 1 ～７番号付けし，七つ のデータセット（7 パターンの入出力データ）を示す. なお, 降雨量, 日照時間の值は各月の平均值, 糖度とク エン酸含量の值は果実 6 個の平均值である。図より，糖 度は，年によって初期值 (8月での值), 経時変化, 最 終段階（11月）での值が大きく異なり，たとえば最終 段階での年度間の標準偏差は $\pm 1.62(12 \%)$ であり，あ る程度のばらつきがみられる。これに対してクエン酸含 量は，いずれも同じような変化パターンを示し，最終段 階での值も標準偏差が $\pm 0.17(4 \%)$ であり，年度間の ばらつきは小さい.

さて, 各年における糖度の違いは何に起因しているの だろうか．気象要因に的を絞ると，一般的には，糖度は 気温（最高気温，最低気温を含む），降雨量，日照時間 などに影響される (Ikeda et al., 1983). しかし，ここ では実際のデー夕に基づいて考える。気温は毎年同じよ 

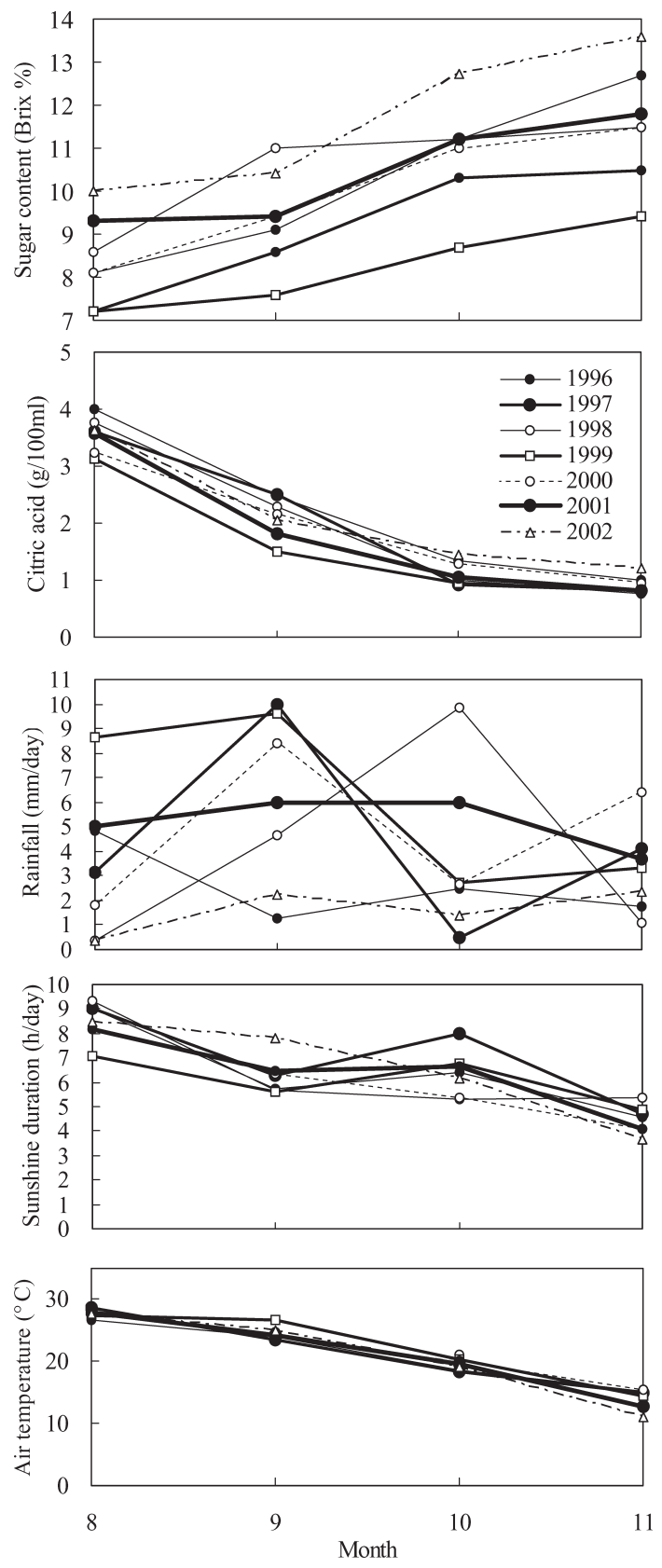

図 3 気象要因 (降雨量, 日照時間, 気温)に対する 温州ミカンの糖度とクエン酸含量の経時変化

Fig. 3 Observed time course changes in the sugar content and the citric acid of the fruit as affected by rainfall, sunshine duration and air temperature.
うな変化をしており，年による差はほとんどないことが わかる，最高・最低気温についてもだいたい同様な傾向 を示した。このことから，気温の影響は少ないと考えら れる。 日照時間については，年によってある程度の違い が見られるが，そんなに大きな差に見えない．これらに 対して, 降雨量は年による差異が顕著であり, 各月によ っても大きく変動している.これらのことから, 愛媛県 八幡浜地方における各年の糖度の違いは主に降雨量の違 いから生じていると推測できる。降雨量がミカンの糖度 に多大な影響を与えることについては多くの報告があり (Sakamoto and Okuchi, 1968; Hase, 1992), 夏から秋 にかけての降雨をマルチで抑制し糖度を上げる研究が行 われている (Matsumoto et al., 1991; Nakazato et al., 1996).

したがって, 本研究では, 入力としては降雨量と日照 時間の二つを選び，また出力としては糖度とクエン酸含 量の二つを選んだ.

なお, 入力（糖度に影響を与える環境要因）として気 温も十分考えられるが，気温は毎年同じような変化を示 し，それが年による糖度の違いに影響しているとは考え られないので，ここでは省いた，本研究のように，シス テム同定法に基づいて, 各年毎の入出力データを学習し てモデルをつくろうとする場合, 各年の出力の違いに影 響を与えない入力は極力避けた方がモデル化しやすいと 考えられる.

\section{2. 入力と出力の関係}

つぎに, 簡易な方法で入力 (降雨量, 日照時間) と出 力（ミカンの糖度，クエン酸含量）の関係をみる. 図 4 は図 3 における降雨量と糖度, 日照時間と糖度の時系列 データをそのまま平面上にプロットし，入出力の静的な 関係を示したものである. 気象データについてはその月 の平均值を用いているが, 糖度は経時変化を単純にプロ ットしただけなので，正確に静的な関係を表していると は言えないが，ある程度の入力と出力の関係が読みとれ る。（a）は降雨量と糖度の関係，（b）は日照時間と糖 度の関係である。両図とも入力と出力の関係は非常にば らついており，すなわち同じ（もしくは同じような）入 力でも出力の值は異なる場合があり, 相関係数は非常に 低い。なお，他の方法で静的な関係を調べても，たとえ ば気象データの 1 ケ月の積算值を用いても，同様な結果 であった。

ここで, ばらつきの原因を考えると, 計測誤差（雑 音), 他の環境要因の影響 (外乱), 個体差, 生物がもと もともっている “ゆらぎ” (Crutchfield et al., 1986; Tawara, 1991; Aihara and Tokunaga, 1994）などが考 


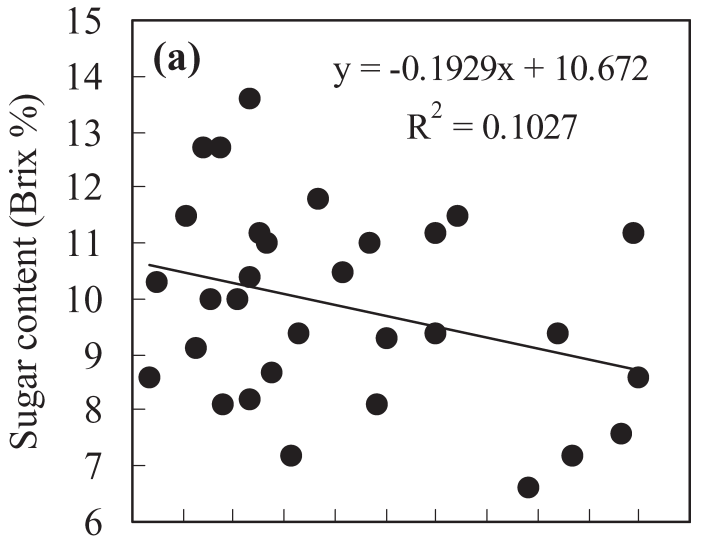

$\begin{array}{llllllllllll}0 & 1 & 2 & 3 & 4 & 5 & 6 & 7 & 8 & 9 & 10 & 11\end{array}$

Rainfall (mm/day)

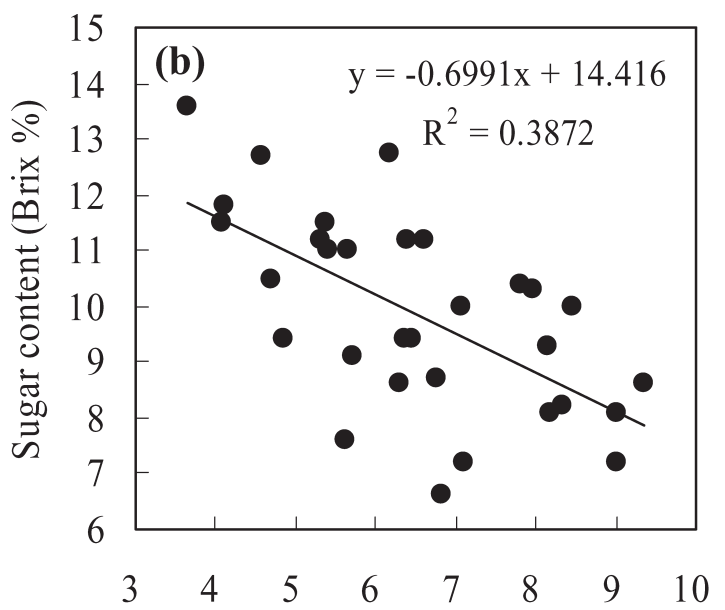

Sunshine duration (h/day)

図 4 降雨量と糖度および日照時間と糖度の静的関係

Fig. 4 Static relationships between rainfall and sugar content and between sunshine duration and sugar content.

えられる。個体差やゆらぎに関しては植物自体の問題な ので, 結局, 植物応答データのばらつきは避けることが できない問題と言える。したがって，単に入出力関係を 調べるだけでは統計的に処理するだけでよいが，モデル 化や制御などを考えると，目的に合うように，うまくデ 一夕処理する必要がある。本研究では, 結果の項で示す が，すべてのデータセットをモデル検証に使って予測誤 差を求め, それらの平均值でモデルの予測精度を比較し
た.

3. ニューラルネットワークによるモデル化

さて，このような入出力関係にばらつきがあるシステ ムをどのようにモデル化すればよいのだろうか。一般に よく用いられるモデルは数式モデルであるが，その出力 は決定論的に一つの值しか得られないので，ばらつき具 合を表現できない。このため, 通常は統計的に処理して 回帰曲線（数式モデル）を求め, 平均值と標準偏差を付 加してばらつき具合を表現する。しかし，このままでは， ばらつきを認めているので，モデルによる予測值と実際 の值とは一致しない場合が多い．結局，ばらつきの大き なシステムに関して, 数式で精度の高いモデルをつくろ うとしても根本的に無理がある.

つぎに，ニューラルネットワークによるモデル化をみ る。ニューラルネットワークは人間と同じょうに，入力 （原因）と出力（結果）の関係（ここでは入出力の変動 パターン）を学習することによって，入出力に関わるモ デルを構築できる。従来の回帰曲線などの手法より，推 定精度が高いことが報告されている (Elizondo et al., 1994).

本報におけるモデル化は, 図 3 の七つのデータセット の内, 六つを学習用に用いてモデルを構築し, 残り一つ をそのモデルの精度を確かめるための検証用に用いた。 なお，検証は予測值と実測值の差を評価することで行わ れる。

さて，ニューラルネットワークによるモデル化では， 主にシステムパラメータの数（何個前までのデータを用 いて出力を計算するか）と中間層ニューロン数を決定す ればよいが，ここではデータがばらついているので，過 剩学習 (over learning) に注意しなければならない (Liu et al., 2001).

まず，学習回数について調べた，図 5 は，二つ前まで の時系列デー夕を用いて出力值を予測するプログラムを 用いて，データセット 1 をモ゙ル検証用とした場合の学 習回数とモデル検証誤差の関係である。（a）は糖度， （b）はクエン酸含量の場合である。白抜きは学習誤差, 黒塗りはモデル検証誤差である。モデル検証誤差は学習 誤差よりかなり大きいのが分かる，両図とも，学習回数 が増すに従って学習誤差は小さくなる。しかしモデル検 証誤差はある值までは小さくなるが，それ以上では逆に 大きくなった。この原因は過剩学習のためと考えられる。 すなわち，ばらついているデー夕を過剩学習すると，学 習プロセスでは誤差が小さくなるが，学習用データに偏 り過ぎるので，まったく別のデー夕を用いた検証のプロ セスでは，逆に誤差が大きくなっていると考えられる． 


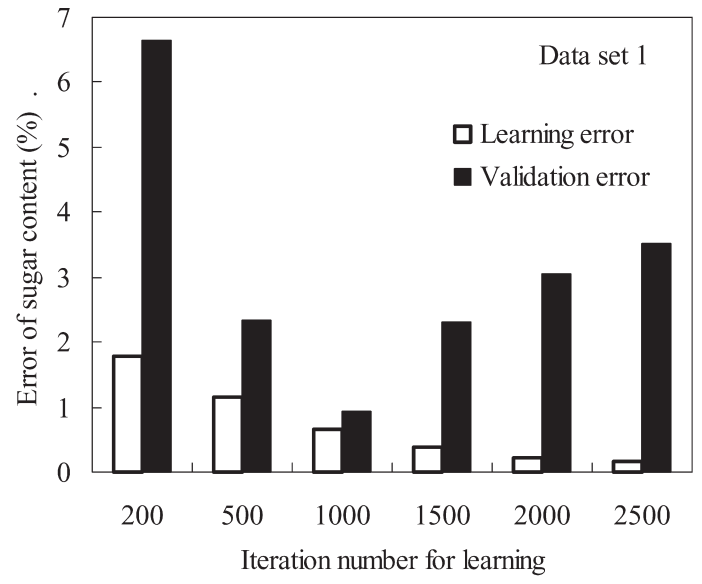

(a) Sugar content

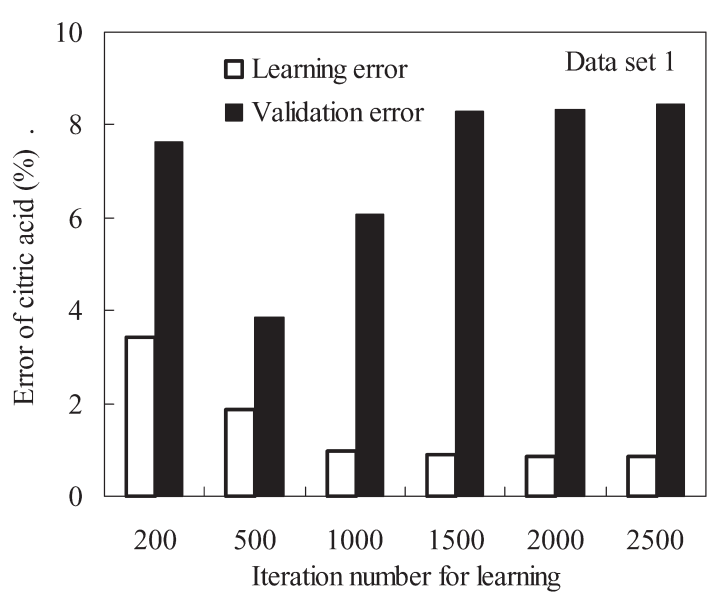

(a) Citric acid

図 5 学習回数と学習誤差およびモデル検証誤差 (データセット 1 をモデル検証用に使う)

Fig. 5 Validation and learning errors (\%) versus iteration number for learning. The data set 1 was used for validation.

したがって学習回数は，糖度およびクエン酸含量のモデ ル検証誤差が最小となる学習回数 $=1,000$ 回を選び, 以 後これを学習回数とした。

図 6 は，七つのデータセットにおいて，各データセッ ト一つをそれぞれモデル検証用に用いた場合の各データ セットとモデル検証誤差の関係である，たとえば，デー タセット 1 をモデル検証用に用いたときは, 他の 2 7 は学習用であり，そのときのモデル検証誤差は 0.12 で ある。なお，この場合のシステムパラメータ数は 2 , 繰 り返し回数は 1,000 回, 中間層ニューロン数は 8 とした.

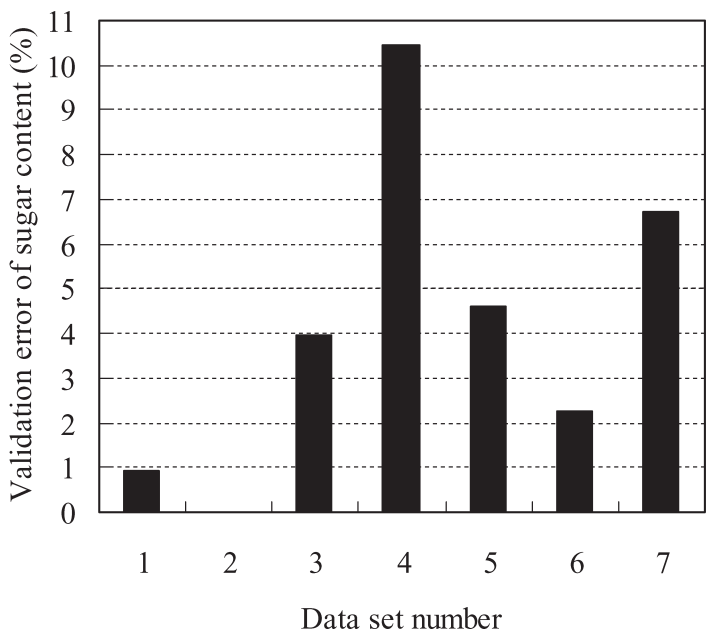

図 6 データセット 1 ～7 がそれぞれモデル検証用に 使われた場合の糖度のモデル検証誤差

Fig. 6 Validation error for sugar content in the case that each data set $1,2, \ldots$, or 7 was used for validation.

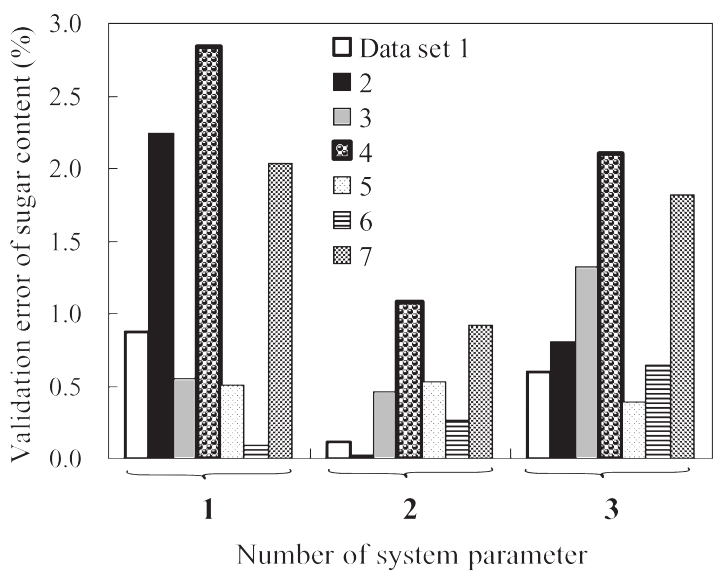

図 7 データセット 1〜 7 がそれぞれモデル検証用に 使われた場合のシステムパラメータ数と糖度の モデル検証誤差.

Fig. 7 Validation errors for the sugar content versus the number of system parameter $(=$ 0,1 and 2) in the case that each data set 1 , $2, \ldots$, or 7 was used for validation.

図より，どれをモデル検証用のデータセットにするかに よってモデル検証誤差が大きく異なるのがわかる.

図 7 は, システムパラメータ数とモデル検証誤差の関 係である，前述したように，モデル検証誤差は，どのデ ータセットをモデル検証用に用いるかで值が大きく異な るので, ここでは各システムパラメータ数 $\mathrm{n}=0,1,2$ に おいて，七つのデータセット各 1 個ずつをモデル検証用 
表 1 図 7 での各シスラムパラメー夕数 $(0,1,2)$ とモデル検証誤差 (七つのパターンの平均値士標準偏差)

Table 1 Average values and standard deviations for system parameter number in Fig. 7.

\begin{tabular}{cc}
\hline \hline $\begin{array}{c}\text { Number of system } \\
\text { parameter }\end{array}$ & $\begin{array}{c}\text { Validation error for } \\
\text { sugar content }(\%)\end{array}$ \\
\hline 0 & $11.9 \pm 10.7$ \\
1 & $4.3 \pm 3.9$ \\
2 & $9.8 \pm 6.7$ \\
\hline
\end{tabular}

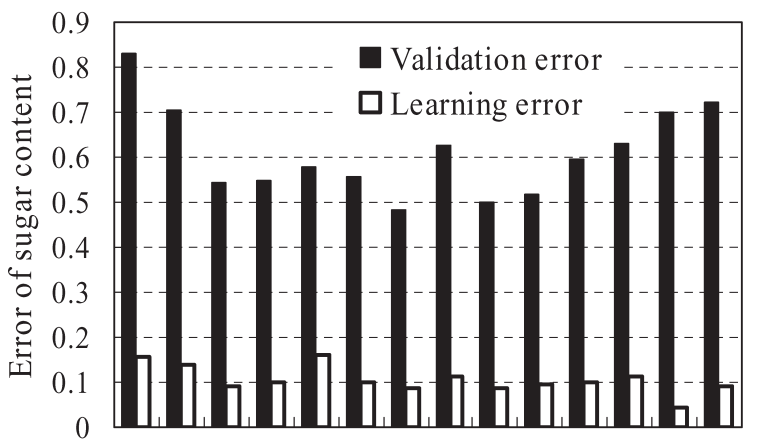

$\begin{array}{lllllllllllllll}2 & 3 & 4 & 5 & 6 & 7 & 8 & 9 & 10 & 11 & 12 & 13 & 14 & 15\end{array}$ Hidden neuron number

図 8 中間層ニューロン数と学習㧍よびモデル 検証誤差（7 パターンの平均值）の関係

Fig. 8 Average learning and validation errors of all data sets for sugar content versus hidden neuron numbers.

に用いた場合の誤差を示している。なお，システムパラ メータ数としては（予測に何個前までのデータを用いる かは)，0,1,2の三つの值しか示していない。これは 8 〜11月までの四つのデー夕しかないので, 最後の四つ 目を予測するには現在 $(n=0)$, 一つ前 $(n=1)$, 二つ前 (n=2)までのデー夕を使うからである。表 1 は，この ときの各システムパラメータ数におけるモデル検証誤差 の平均值と標準偏差である。図および表より，システム パラメー夕数が 1 のときのモデル検証誤差が最小である のがわかる。このことは，現在と一つ前までのデー夕を 用いてモデル化するのが最良であることを示している. あまり過去までデー夕を長く取って学習すると, 検証で は逆に誤差が増大する場合がある。この原因は, やはり データがばらついていることに起因すると考えられる.

図 8 は，中間層ニューロン数とモデル検証誤差の関係 である。このデータは 1 ～７各データセットを 1 個ず つモデル検証用に用いた場合の学習誤差とモデル検証誤 差の平均值を示している．顕著な差はあまり見られない が，中間層ニューロン数が 8 のとき, モデル検証誤差が 最小となった。このため, 中間層ニューロン数は 8 を選
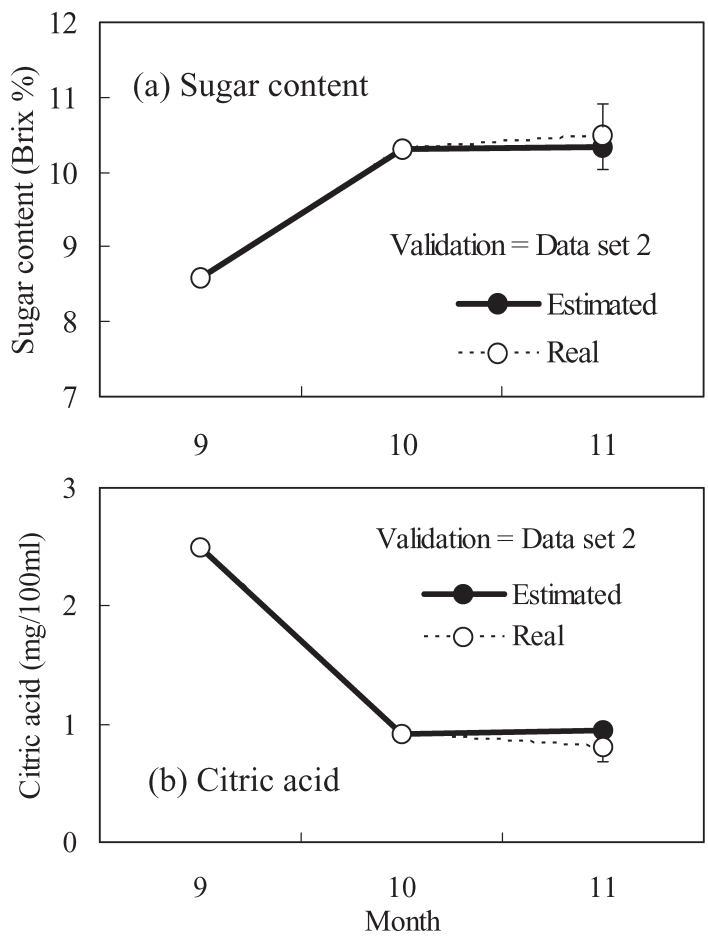

図 9 気象要因 (降雨量と日照時間) の 1 ヶ月前 $(9$ 月), 今月 (10月), さら飞 1 ケ月先 (11月) の時系列データと果実応答（糖度とクエン酸含 量）の 1 ケ月前，今月の時系列デー夕から， 1 ケ月先の收穫期（11月）に扔ける果実応答を 予測した場合の予測值と実測値（平均値士標準 偏差で表す）との比較。なお，1 月月先 (11 月）の気象デー夕は天気予報の 1 ケ月予報を利 用する.

Fig. 9 Comparisons of the estimated and observed responses of the sugar content and the citric acid of the fruit in the case that the data set 2 was used as a validation. In each figure, only the value at the final time point (November) was predicted by using the past two data at the present (October) and one step ago (September). Real values of the sugar content and the citric acid at their final time points were described in their average values and standard deviations. 
んだ.

図 9 は，一例としてデータセット 2 をモデル検証用と し, 最適な学習回数 $(1,000)$, システムパラメータ数 （1），中間層ニューロン数（8）を選んで予測した場合の 糖度とクエン酸含量の予測值と実測值との比較である。 なお，予測する 11 月の実測值については，ばらつき具 合（標準偏差）も示している。両者とも，予測值は実測 值とよく一致しており，ばらつきの範囲内に十分収まっ ているのが分かる.

以上の結果は，本手法が複雑な気象条件に対する果実 の品質特性を予測するのに有効であることを示している.

\section{結 論}

本研究は, ニューラルネットワークを用いて, 過去 7 年間，8～11 月にかけての温州ミカン栽培における気象 (降雨量と日照時間) および果実の品質（糖度とクエン 酸含量）の時系列データを学習し, 収穫時期（11月） における品質を，それまでの（8～10月までの）気象お よび品質の時系列データから予測するモデルを開発した。 2 入力 $($ 降雨量と日照時間 $)-2$ 出力 $($ 糖度とクエン酸含 量）モデルである.

1. 計測された入力（降雨量と日照時間）と出力（糖 度とクエン酸含量）の関係はばらつきが大きく相関が低 かった。

2. ばらつきの大きなデータでは, 学習用および検証 用に，どのデータセットを選ぶかで，モデルの精度がか なり異なった。このため，学習用，検証用のデータセッ トをいろいろ変えてモデル化し，モデル検証誤差の平均 值を求め，それを最小とするパラメータを選ぶのが妥当 と考えられた。

3. システムパラメータ数は，モデル検証誤差を最小 にするような值を選ぶことが重要であり，本実験では 1 が最適であった。すなわち，現在と一つ前（1ヶ月前） までの降雨量と日照時間の值および糖度とクエン酸含量 の值を用いれば，次の月（1ヶ月先）のミカンの糖度と クエン酸含量を精度良く予測できると分かった。

4. 本研究は, 対象としてフィールドで栽培されてい る温州ミカンを用いた研究結果であるが, 内容はモデル 化の方法論が中心であり，この成果は温州ミカンの温室 栽培や植物工場等での栽培にも十分応用できる。

\section{摘 要}

本研究は，ニューラルネットワークを利用して，温州
ミカンの収穫時期における品質（糖度とクエン酸含量） の值を，それまでの品質および気象の時系列データから 予測するモデルを開発した。学習およびモデル検証用の データは， 7 年間，8～11月にかけて収集された七つの データセットであり，各データは 4 点（8～11月）の時 系列からなる。このうち六つを学習用に，一つをモデル 検証用に用いた。品質に大きな影響を与える気象要因は 降雨量と日照時間であり，とくに降雨量が顕著であった。 それで 2 入力 (降雨量と日照時間) -2 出力 (糖度とク エン酸含量）モデルを構築した。 入力（気象要因）と出 力（果実の品質）の関係は，非線形特性が強く，また実 測デー夕のばらつきが大きいので数式によるモデル化は 困難であるが， 3 層のニューラルネットワークを用いて， 入力と出力の現在および過去の時系列データを使用し, 最適な学習回数, システムパラメータ数, 中間層ニュー ロン数を選ぶことにより，精度の高いモデルを構築でき た。

\section{引用文献}

Aihara, K. and Tokunaga, T. 1994. Applied strategy of chaos (in Japanese) (カオス応用戦略). Ohmsha, Tokyo, 48-57.

Chen, S., Billings, S.A., and Grant, P.M. 1990. Nonlinear system identification using neural network. International Journal of Control 51(6) : 11911214.

Crutchfield, J. P., Farmer, J. D., Packad, N. H. and Show, R. S. 1986. Chaos. Scientific American, December, 62-68.

Elizondo, D. A., McClendon, R. W., Hoogenboom, G. 1994. Neural network models for predicting flowering and physiological maturity of soybean. Transactions of the ASAE 37 (3) : 981-988.

Fasol, K. H. and Jorgl, H. P. 1980. Principles of model building and identification. Automatica, $16: 505^{-}$ 518.

Hase, Y. 1992. Soil water and fruit, Fruit tree edition, Systems of Agricultural Technologies (in Japanese) (土壌水分と果実, 農業技術体系果樹編). Rural Culture Association, Tokyo, 59-64.

Hint, G. E. 1992. How neural networks learn from experience. Scientific American 12 : 105-109.

Hirose, K. 1987. Research method for citrus (in Japanese) (カンキツの調査方法)， Edited by Okitsu Branch in National Institute of Fruit Tree Science(農林水産省果樹試験場興津支場編)，5-11.

Ikeda, K., Taoka, A., Kimura, S., Ono, S., Nakanishi, M. Fujita, S. 1983. Effects of climatic factors and growth on the change of yield of Satsuma mandarin (in Japanese) (温州ミカンの収量変動に及ぼす 
気象要因と生育諸形質の影響). Bulletin of Shikoku Agricultural Experimental Station, $41: 18-44$.

Isermann R., Ernst, S., Nelles, O. 1997. Identification with dynamic neural. Preprints of 11th IFAC Symposium on System Identification $3:$ 997-1022.

Liu, J., Goering, C. E., Tian, L. 2001. A neural network for setting target corn yields. Transactions of the ASAE 44 (3) : 705-713.

Matsumoto, K., Oba, Y., Yahata, D. and Tsuda, K. 1991. Studies on the cultivation of covered with multing film in Satsuma mandarin trees (1) Effects of soil-water management on fruit quality of Satsuma mandarin (in Japanese) (温州ミカンの フィルムマルチ栽培に関する研究（第 1 報）温州ミ カンの品質に及ぼす土壤水分の影響). Bulletin of Fukuoka Agricultural Research Center, B-11：73 -76 .

Nakazato, I., Matsunaga, S. and Kishino, I. 1996. Effects of strength, period of dry stress on fruit quality in film-mulching Satsuma mandarin trees (ウンシュウミカンのフィルムマルチ栽培における 乾燥ストレスの期間及び程度が果実品質に及ぼす影 響)。 Bulletin of Nagasaki Fruit Tree Experimental Station $3: 1-10$.

Narendra, K. S. and Parthasarathy, K. 1990. Identification and control of dynamical systems using neural networks. IEEE Transactions on Systems, Man, and Cybernetics, 1(1) : 4-27.

Nakano, H., IInuma, K., Fushikida, K., Iso, K. Kiku- chi, Y., Doya, S. and Ito, K. 1990. Neuro-computer (in Japanese) (ニューロコンピュータ). GijutsuHyohronsha, Tokyo, 24-84.

Recknagel, P., French, M., Harkonen, P. and Yabunaka, K. 1997. Artificial neural network approach for modelling and prediction of algal blooms. Ecological Modelling $96: 11-28$.

Rumelhart, D. E., Hinton G. E., Williams, R. J. 1986. Learning representation by back-propagation error. Nature $323(9): 533-536$.

Sagara, S., Akizuki, K., Nakamizo, T. and Katayama, T. 1981. System identification (in Japanese) (シス テム同定). The Society of Instrument and Control Engineers, Tokyo, 75-179.

Sakamoto, T. and Okuchi, S. 1968. Effects of rainfall on soluble solids and acid in Satsuma oranges (in Japanese) (温州ミカン果実の可溶性固形物, 酸に 及济す降水量の影響)。 J. Jpn. Soc. Hort. Sci. 37 (3) : 212-220.

Strejc, V. 1980. Least squares parameter estimation. Automatica, 16, 535-550.

Tan, S. S. and Smeins, F. E. 1996. Predicting grassland community changes with artificial neural network model. Ecological Modelling 84: 91-97.

Tawara, T. 1991. Chaos and health (in Japanese) (カ オスと健康), Popular Medicine(からだの科学), 161:94-102.

Thornley, J. H. M. 1976. Mathematical models in plant physiology. Academic Press, London, 1-232. 